\title{
Spatial and temporal variation of uranium in a shallow weathered rock aquifer in southern India
}

\author{
$\mathrm{K}$ BRINDHA $^{1}$, L ElAngO ${ }^{1, *}$ and R N NAiR ${ }^{2}$ \\ ${ }^{1}$ Department of Geology, Anna University, Chennai 600 025, India. \\ ${ }^{2}$ Environmental Assessment Division, Bhabha Atomic Research Centre, Mumbai 400 085, India. \\ ${ }^{*}$ Corresponding author.e-mail: elango34@hotmail.com elango@annauniv.edu
}

\begin{abstract}
Uranium occurs naturally in groundwater and surface water. The objective of this study is to understand the causes for the occurrence of uranium and its spatio-temporal variation in groundwater in a part of Nalgonda district, Andhra Pradesh, south India. Uranium deposits occur in the southeastern part of this area. Groundwater samples were collected from 44 wells every two months from March 2008 to January 2009. The samples were analyzed for $\mathrm{pH}$, ORP and uranium concentration. The uranium concentration in groundwater varies from $0.2 \mathrm{ppb}$ to a maximum of $68 \mathrm{ppb}$ with a mean of $18.5 \mathrm{ppb}$. About $21.6 \%$ of the samples were above the drinking water limit of $30 \mathrm{ppb}$ set by USEPA. The uranium concentration varied with fluctuation in groundwater level, $\mathrm{pH}$ and ORP. Uranium concentration in groundwater changes depending on lithology, degree of weathering and rainfall recharge.
\end{abstract}

\section{Introduction}

Uranium is a naturally occurring radionuclide in surface and groundwater. Natural uranium is a mixture of three isotopes $-{ }^{238} \mathrm{U},{ }^{235} \mathrm{U}$ and ${ }^{234} \mathrm{U}$. Its average abundance in the earth's crust is about $2 \mathrm{ppb}$. It occurs naturally in rocks and minerals such as granite, lignite, phosphate deposits and in uranium minerals such as uraninite, carnotite and pitchblende. Uranium also occurs in low concentration in all natural waters. Intake of uranium can cause chemical as well as radiological toxicity which usually affects the kidneys (through ingestion from water or food) and the lungs (through inhalation). Zamora et al (1998) had reported cases of kidney disorders due to ingestion of drinking water containing uranium as high as $780 \mathrm{ppb}$. Garshasbi et al (2005) reported the uranium concentration in seawater of Caspian Sea and Persian Gulf to be around $6.12 \pm 0.18 \mathrm{ppb}$ and $3.53 \pm 0.1 \mathrm{ppb}$. The association of uranium with colloidal and suspended particulate matter in Arabian Sea was studied by Singhal et al (2004). The concentration of uranium in various rivers of India such as Yamuna (0.09-3.61 ppb) and Chambal (0.2$1.74 \mathrm{ppb}$ ) (Rengarajan et al 2006), Bhagirathi (2.11-3.96 ppb) and Alakanda (1.86 ppb) (Sarin et al 1992) have been studied earlier. Springs and streams in Himachal Pradesh, India had 0.07 to $4.65 \mathrm{ppb}$ of uranium (Singh et al 1999). Similarly uranium concentration in groundwater has been reported in several parts of India - Kumaun and Siwalik $(1.08 \pm 0.02$ to $35.83 \pm 0.09 \mathrm{ppb})$ (Ramola et al 1988), Punjab (11.71 \pm 0.15 to $113.70 \pm$ $0.46 \mathrm{ppb}$ ) (Singh et al 1995), Kolar district (0.3 to $1442.9 \mathrm{ppb}$ ) (Babu et al 2008) and Upper Siwaliks $(1.08 \pm 0.03$ to $19.68 \pm 0.12 \mathrm{ppb})$ (Singh et al 2009). The present study was carried out in Nalgonda district, Andhra Pradesh, southern India where occurrence of unconformity related uranium deposits have been reported (Sinha et al 1995). The presence of indoor radon/thoron concentration in this area was reported by Reddy et al (2003). Singh et al (2002) studied the uranium concentration (0.5

Keywords. Uranium; groundwater; Nalgonda; Andhra Pradesh; India. 
to $410 \mathrm{ppb}$ ) in groundwater in Palnadu sub-basin which is located adjacent to the present study area. The causes for the presence of high fluoride concentration in groundwater of parts of Nalgonda district was reported by Brindha et al (2011). However, occurrence of uranium in groundwater in this area as well as its spatial and temporal variation has not been studied. Keeping an account on the importance of public health and considering the fact that there is sizable uranium mineralization in this area, this study was aimed to understand the present status of uranium, the causes, spatial and temporal variation in groundwater in Peddagattu region of Andhra Pradesh, southern India.

\section{Materials and methods}

\subsection{Description of the study area}

The study area forms a part of Nalgonda district, Andhra Pradesh, which is located at a distance of $85 \mathrm{~km}$ ESE of Hyderabad (figure 1). The southeastern side of the study area is surrounded by the Nagarjuna Sagar reservoir and the southern side of the area is bounded by Pedda Vagu river. The northern boundary is bounded by Gudipalli Vagu river. This area experiences arid to semiarid climate. This area goes through hot climate during the summer (March-May) with a temperature ranging from $30^{\circ}$ to $46.5^{\circ} \mathrm{C}$ and in winter (November-January) it varies between $16^{\circ}$ and $29^{\circ} \mathrm{C}$. The average annual rainfall in this area is about $1000 \mathrm{~mm}$ occurring mostly during southwest monsoon (June-September). The topography derived from SRTM (Shuttle Radar Topography
Mission) data is shown in figure 2. In general, the ground surface slopes towards southeastern direction. There are several small hillocks in this area with height ranging from 100 to $200 \mathrm{~m}$. The Lambapur Peddagattu area where the uranium minerals occur are flat topped hills with an elevation of about $300 \mathrm{~m}$ msl. The major rivers Pedda Vagu and Gudipalli Vagu which forms the two boundaries of the study area are seasonal rivers that flows during the southwest monsoon from July to September. The rainfall has led to dentritic to subdentritic drainage pattern in this area (figure 1). Numerous tanks and few small reservoirs are present in the depressed parts of the undulating topography of the study area. There are also wide lined canal networks catering for irrigation purposes. The forest cover is thin to moderate.

Most of the study area comprises of agricultural land. Paddy is the principle crop grown in this area while other crops include sweet lime, castor, cotton, grams and groundnut. Drip irrigation is practiced in this area especially for sweet lime.

\subsection{Geology}

Granitic rock forms the basement of this region, which is traversed by numerous dolerite dykes and quartz veins (figure 3). Most part of the investigated area has exposures of granitic rocks belonging to late Archaen. Granites are generally mediumto-coarse grained. The Srisailam Formation, the youngest member of the Cuddapah Supergroup uncomformably overlies the basement granite with a distinct unconformity. The Srisailam Formation is exposed in the southeastern part of the

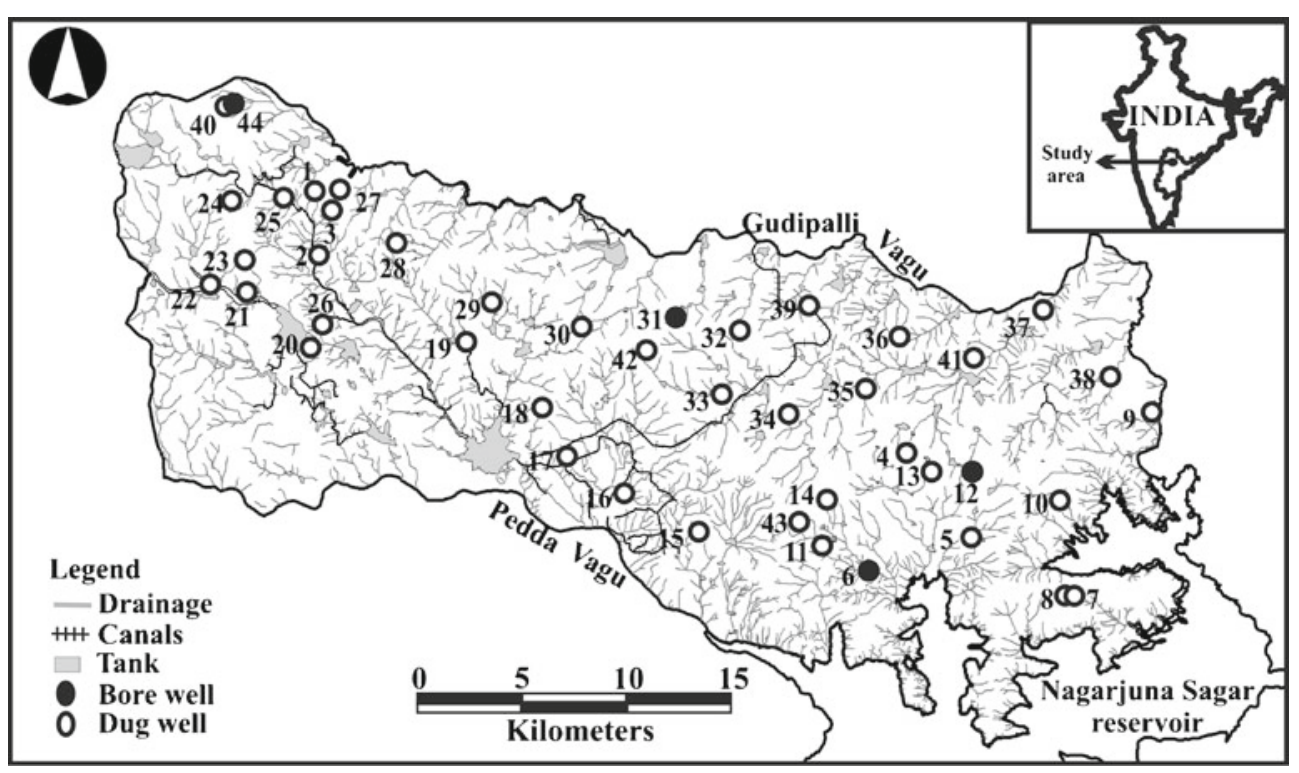

Figure 1. Location of the study area with drainage and monitoring wells. 


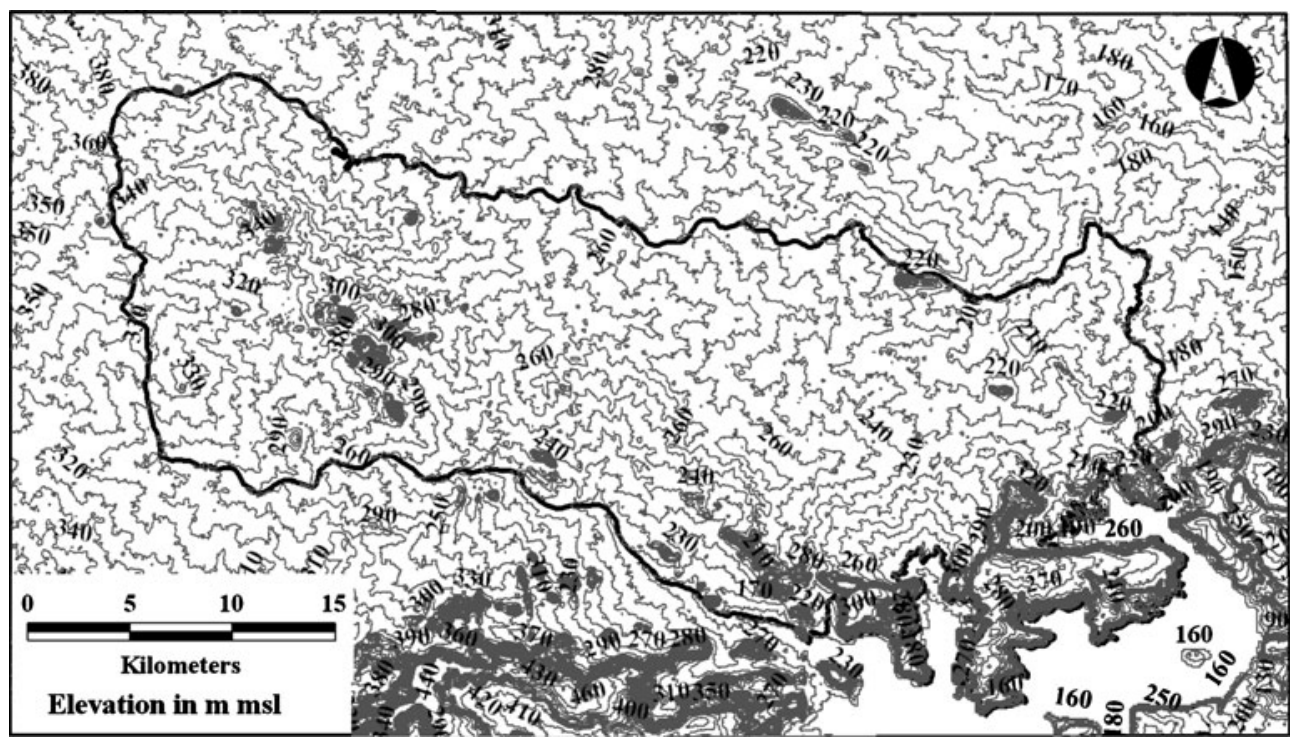

Figure 2. Topography.

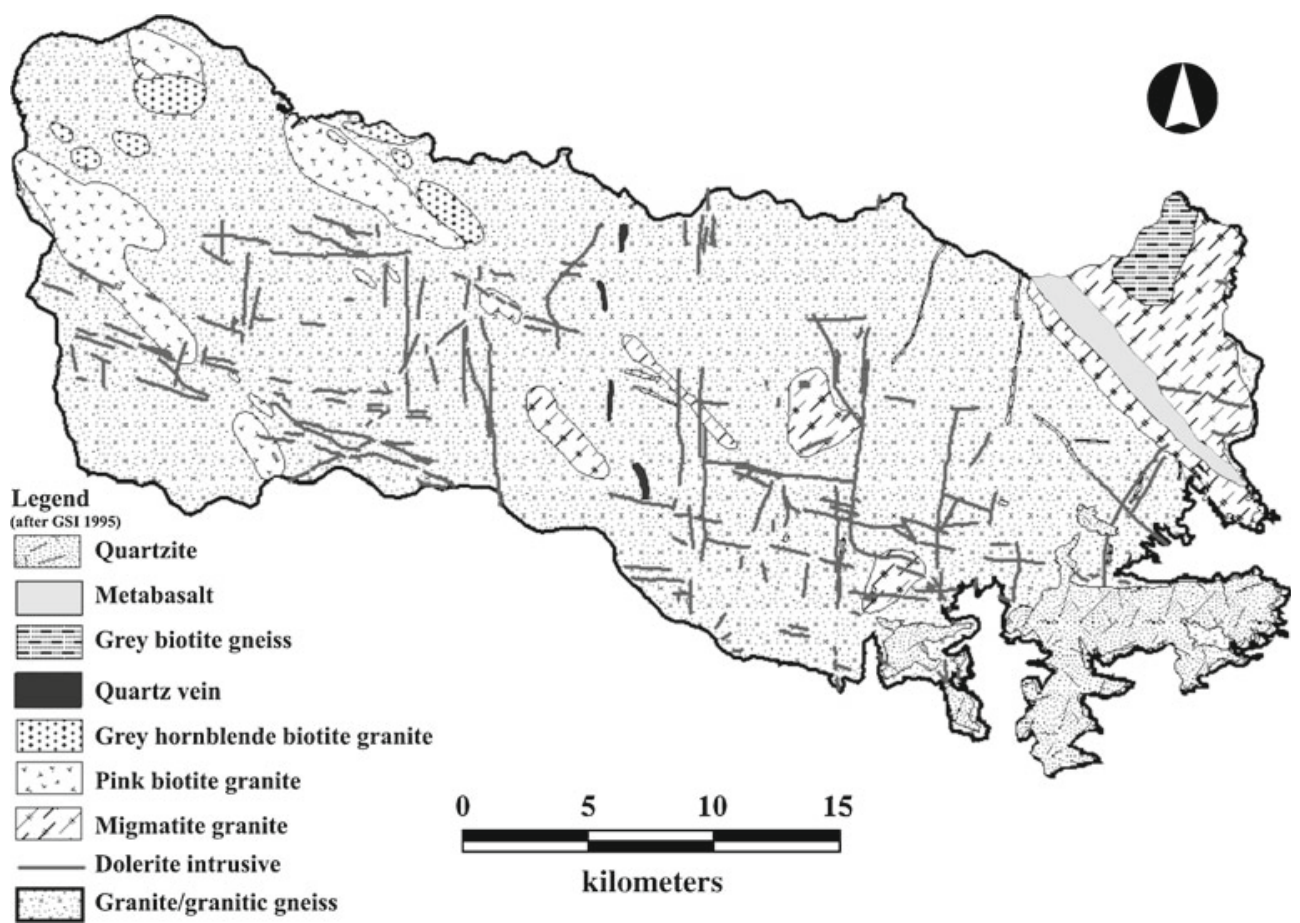

Figure 3. Geology.

study area. The sediments of Srisailam Formation are mainly arenaceous and include pebblygritty quartzite shale with dolomitic limestone, intercalated sequence of shale-quartzite and massive quartzite. The litho units of this formation are dipping at an angle ranging from $3^{\circ}$ to $5^{\circ}$ towards SE. The generalized stratigraphic sequence of this area is given in table 1 (after GSI 1995). The uranium deposit occurs adjacent to the unconformity between basement granite and the overlying Proterozoic Srisailam quartzite in the northwestern margin of the Cuddapah basin. Uraninite, pitchblende, kasolite and uranophane are the main uranium minerals present in the deposits of Lambapur and Peddagattu (Sinha et al 1995). The primary uranium mineralization is of epigenetic hydrothermal in nature (Singh et al 2002). Lambapur mineralized zone occurs at shallow depth of about 10$15 \mathrm{~m}$ whereas it occurs below $50 \mathrm{~m}$ or more in Peddagattu. The granitic rocks of this region contain uranium in the range of $10.2-116 \mathrm{ppm}$ with an average of $35 \mathrm{ppm}$ (Shrivastava et al 1992). 


\subsection{Hydrogeology}

Hydrogeology of the study area was arrived based on field work, monitoring of groundwater levels, pumping tests and infiltration tests. The study area has four distinct layers which are the soil zone, moderately weathered, highly weathered and massive rock. The thickness of soil zone ranges from 0.6 to $12 \mathrm{~m}$. The soil zone is comparatively thicker in the southern and northeastern boundary of the study area due to the influence of rivers. The thickness of the moderately weathered granite ranges from 11 to $77 \mathrm{~m}$ and highly weathered granite layer ranges from 12 to $33 \mathrm{~m}$. Most of the wells penetrate up to the fractured layer. The lithology of a few wells are shown in figure 4 . The groundwater table occur generally from 0 to $12 \mathrm{~m}$ below ground level. The annual groundwater level fluctuation is around $8 \mathrm{~m}$. The principal source of groundwater recharge is rainfall. The groundwater level rises by $1 \mathrm{~m}$ after the monsoon rains in the months of July-September. That is, the groundwater levels before monsoon range from 3 to $7 \mathrm{~m}$ $\mathrm{bgl}$, and after monsoon, it varies from 2 to $3 \mathrm{~m}$ bgl.
Groundwater generally flows towards the southeastern direction. Though there are many igneous intrusions in this area, due to the high intensity of weathering and as groundwater occur at shallow depths they do not act as barriers to groundwater flow. The dug wells of this area range from 1.5 to $20 \mathrm{~m}$ and dug-cum-bore wells up to $70 \mathrm{~m}$. The yield of the irrigation wells ranges between 100 and $150 \mathrm{~m}^{3} /$ day whereas in few places it is up to $200 \mathrm{~m}^{3}$ /day (CGWB 2007). Most of the wells in this area are used for irrigation purposes. The hydraulic conductivity of the study area generally ranges from 0.5 and $18 \mathrm{~m} /$ day. Groundwater plays a predominant role in the net irrigated area by constituting $57.20 \%$, whereas surface water irrigation accounts for $38.63 \%$ in Nalgonda district (CGWB 2007).

\subsection{Sampling and instrumentation}

An intensive field survey was carried out and nearly 240 wells were considered for sampling. The EC (electrical conductivity) $(\mu \mathrm{S} / \mathrm{cm})$ of groundwater

Table 1. Stratigraphic sequence of the study area (after GSI 1995).

\begin{tabular}{ll}
\hline $\begin{array}{l}\text { Cuddapah Supergroup } \\
\text { Srisailam Formation }\end{array}$ & Massive quartzite \\
& Upper shale \\
& Quartzite with shale intercalation \\
& Lower shale with limestone intercalation \\
& Pebbly and gritty quartzite/arenite \\
Uranium mineralized region & Uranite/granitic gneiss with intrusion of \\
Late Archean/Lower Proterozoic & dolorite dykes and quartz veins \\
\hline
\end{tabular}

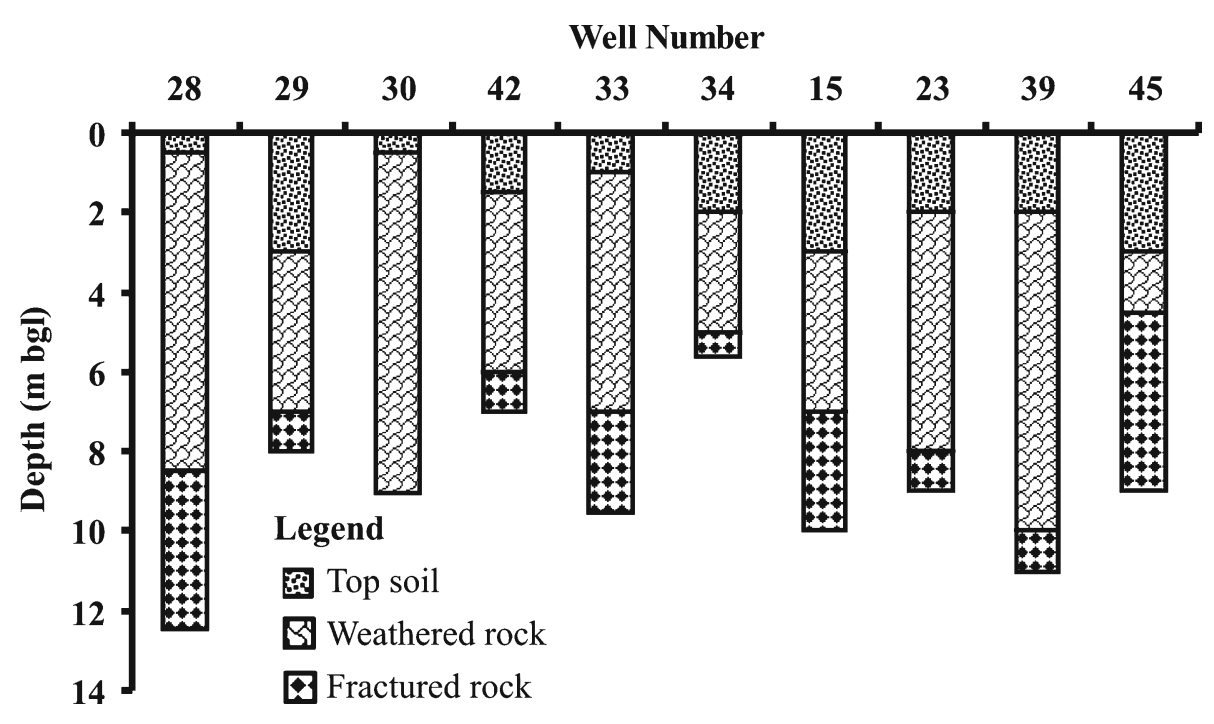

Figure 4. Lithologs of few wells. 

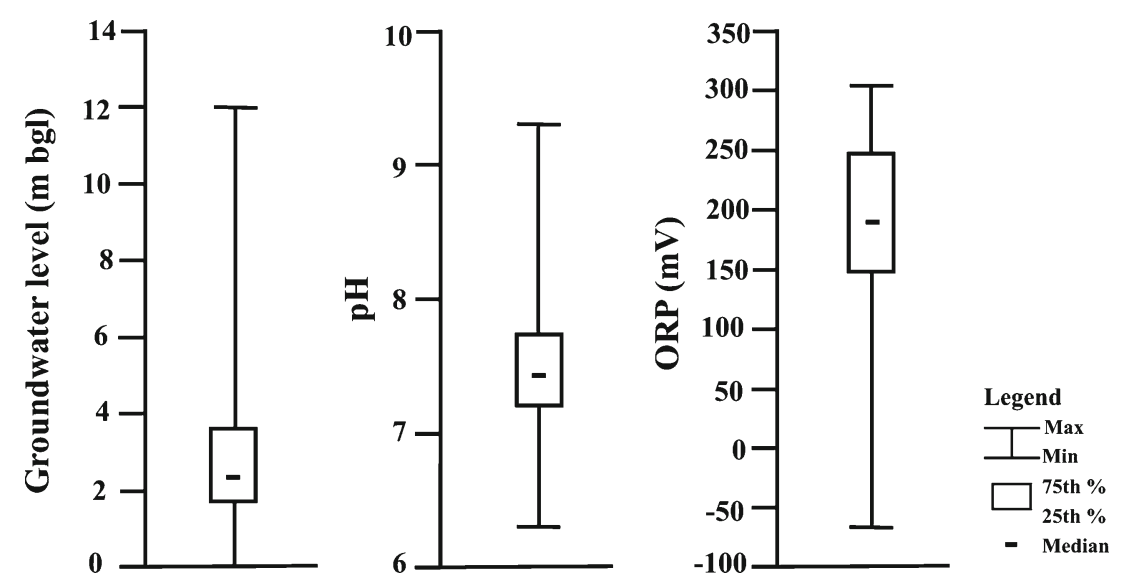

Figure 5. Range and median of parameters measured.

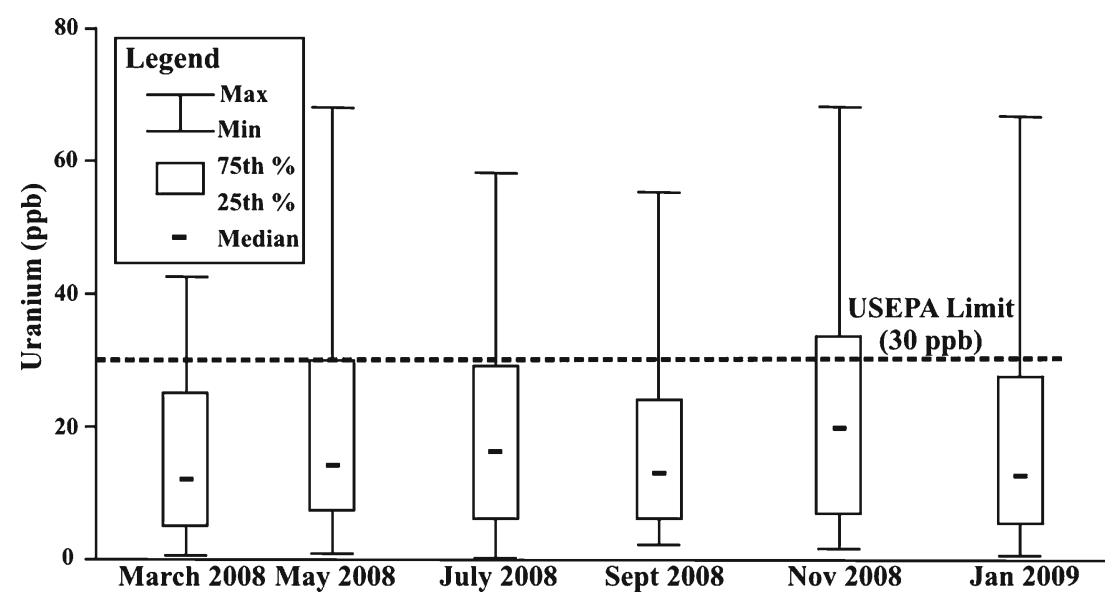

Figure 6. Temporal variation in concentration of uranium in groundwater.

was measured in these wells and a representative well in about every $10 \mathrm{~km}^{2}$ was chosen for regular collection of groundwater samples. In this way, 44 wells (figure 1) were chosen for the collection of representative groundwater samples. Groundwater samples were collected from these wells once every two months from March 2008 to January 2009. Groundwater level (m), pH and ORP (oxidation reduction potential) $(\mathrm{mV})$ were measured in situ. Groundwater level was recorded by using a water level indicator (Solinst 101) while $\mathrm{pH}$ and ORP were measured using Eutech digital portable meters. The $\mathrm{pH}$ meter was calibrated beforehand using 4.01, 7 and 10.01 buffer solution. Quinhydrone 86 and 255 standard solutions were used to calibrate the ORP meter. All the calibrated solutions and instruments were procured from Eutech Instruments. Groundwater samples were collected in clean polyethylene bottles of $500 \mathrm{ml}$ capacity. The sampling bottles were soaked in 1:1 diluted nitric acid solution for 24 hours, washed with distilled water, and were washed again prior to each sampling with the filtrates of the sample. In the case of bore wells, the water samples were collected after pumping the water for sufficient time so as to collect the formation water. Five types of fertilisers commonly used in this area were also collected. Groundwater samples and fertilisers were analysed for their uranium concentration using laser fluorimeter at Health Physics Unit, Nuclear Fuel Complex, Hyderabad, India. Laser fluorimeter works basically on the fluorescence of a uranyl complex formed during the addition of inorganic complexing regent (sodium pyrophosphate) to the sample during the analysis. Nitrogen laser with a wavelength of $337 \mathrm{~nm}$ was used as an excitation source for the determination of uranium concentration in this method (Robbins 1978; Kumar et al 2008). Analysis with a sensitivity of about $0.05 \mathrm{ng} / \mathrm{g}$ (Shawky et al 1994) of uranium can be made 


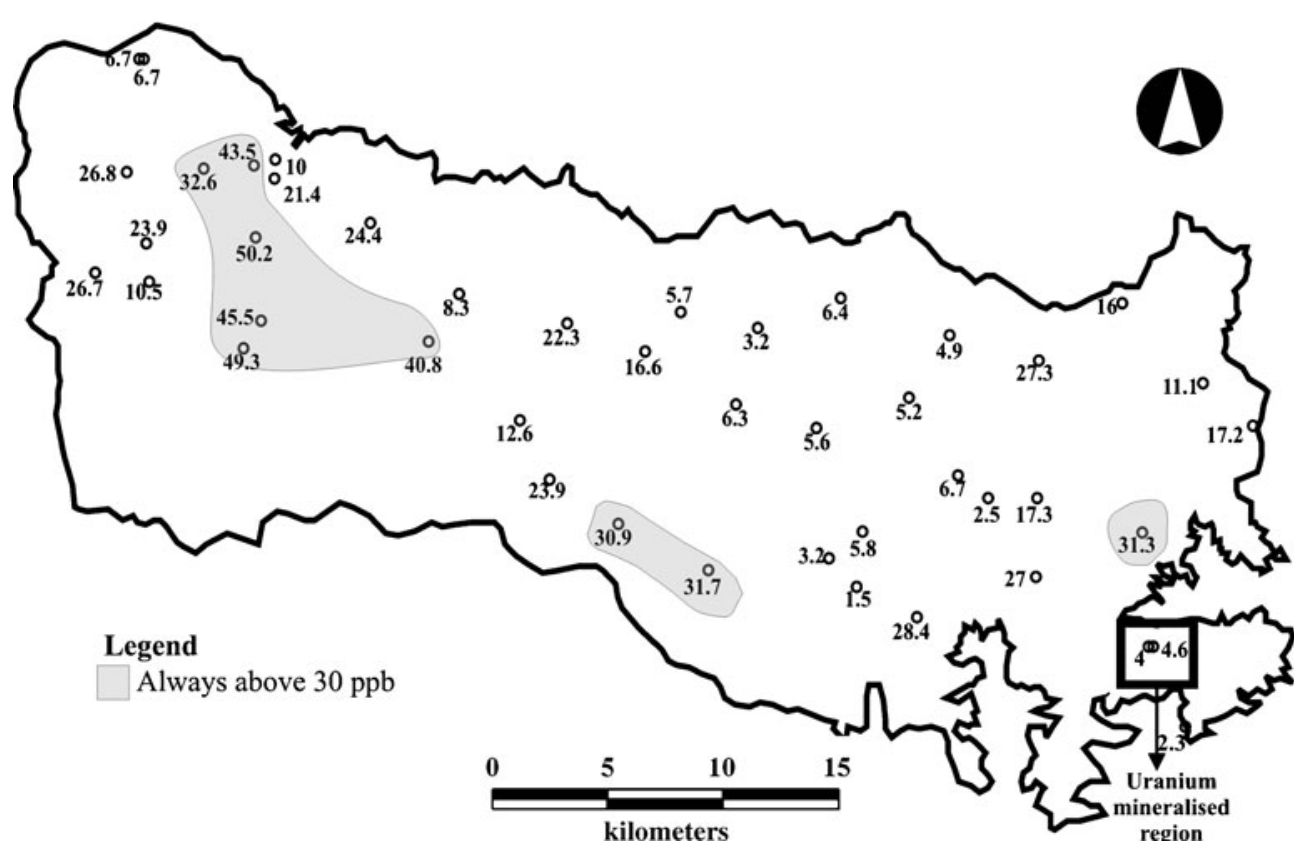

Figure 7. Average uranium concentration (ppb) in groundwater.

without preconcentration or treatment of the sample even in the presence of many potentially interfering species by laser fluorimeter (Sintrex UA-3). Present study used the laser fluorimeter fabricated by Laser Applications and Electronics Division, R.R. Centre for Advanced Technology (CAT), Department of Atomic Energy, Indore, India (Rani and Singh 2006; Kumar et al 2008) which has a detection limit of $0.1 \mathrm{ppb}$. All the analytical reagents used were procured from Merck. Blanks and standards were run simultaneously during the measurement for ensuring accuracy of the result. For every 10 samples, three samples were run in triplicates by varying the concentration of the standard and a calibration curve was obtained to cross check the accuracy of the instrument and to avoid handling errors.

\section{Results and discussion}

The range of groundwater level and the various physical parameters recorded during the sample collection are shown in figure 5. The statistical summary of the uranium concentration obtained from the analysis of groundwater samples during each sampling is shown in figure 6 .

A total of 236 groundwater samples were collected and analysed during this study. The uranium concentration during the study period ranged from 0.2 to $68 \mathrm{ppb}$. The average uranium concentration recorded in sampling wells and in the reservoir from March 2008 to January 2009 is shown in figure 7 . The average concentration of uranium in the groundwater samples was $18.5 \mathrm{ppb}$. The Indian Standards Specifications for drinking water (BIS 1993) does not specify any maximum permissible limit for uranium. Hence, the USEPA (2003) health standard of $30 \mathrm{ppb}$ of uranium in drinking water

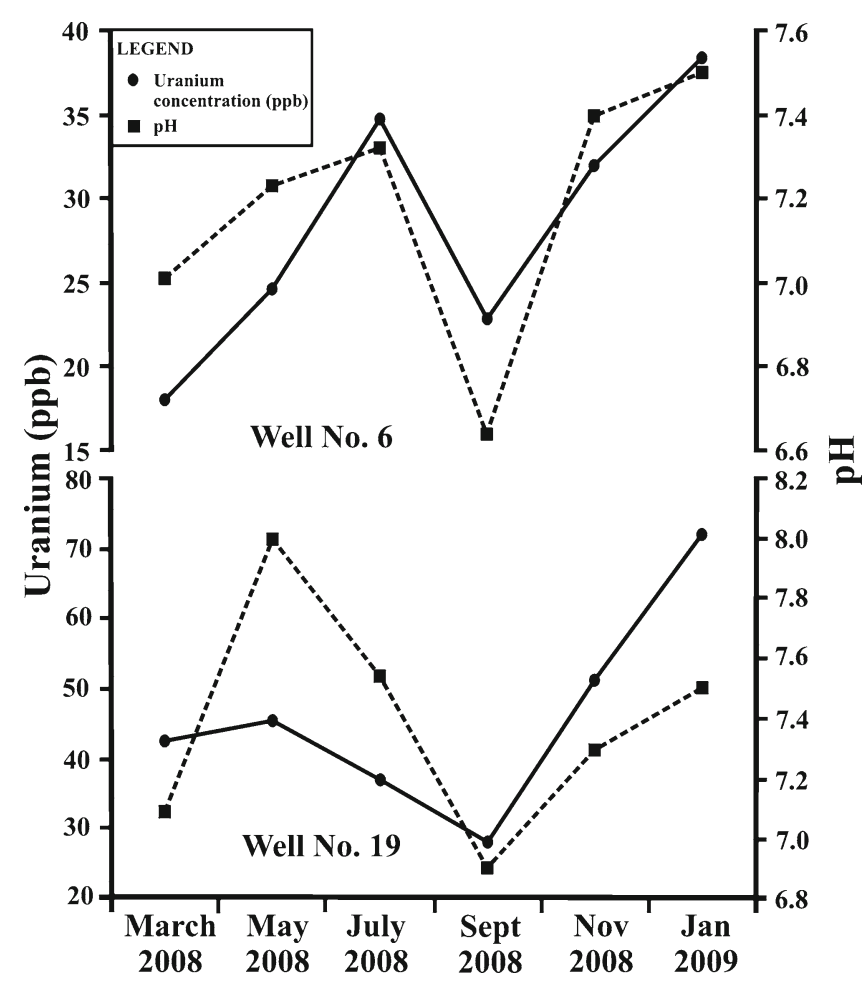

Figure 8. Temporal variation in uranium concentration (ppb) and $\mathrm{pH}$. 


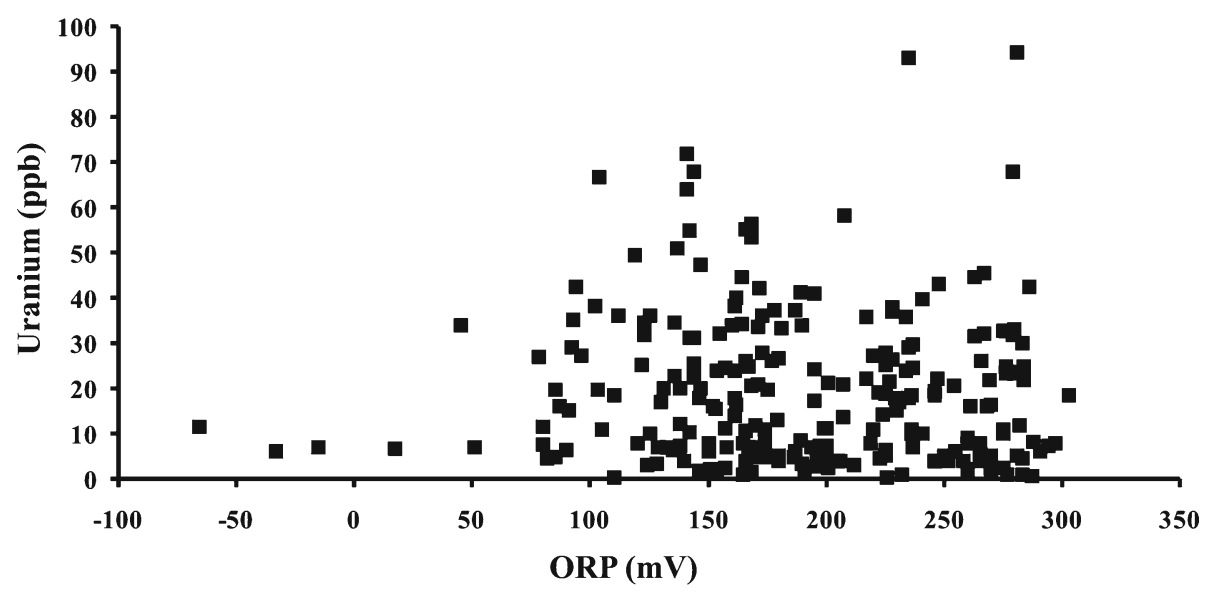

Figure 9. Relationship between uranium concentration (ppb) and ORP (mV).

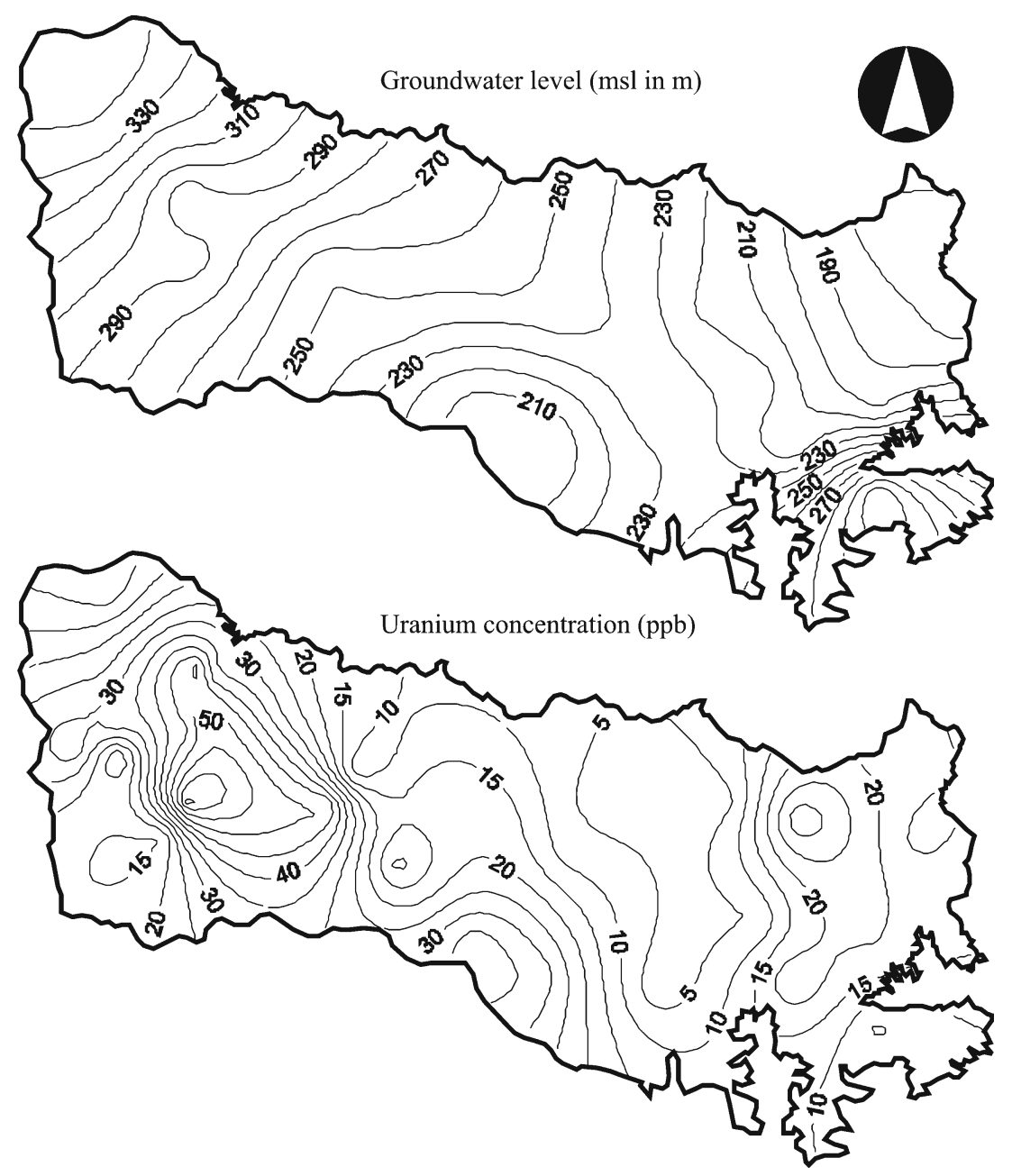

Figure 10. Regional groundwater level (msl in m) and uranium concentration (ppb) in November 2008.

is considered as the limit for this study. Of the total 236 groundwater samples collected and analyzed during the duration of this study, $21.6 \%$ of the groundwater samples had uranium above the USEPA limit. Uranium concentration generally is controlled by the changes in $\mathrm{pH}$ and ORP. In this area the uranium concentration in groundwater varies as in the case of $\mathrm{pH}$ (figure 8). Uranium concentration in groundwater has to be usually higher in oxidised condition which is evident from figure 9 where uranium concentration increases along with ORP 


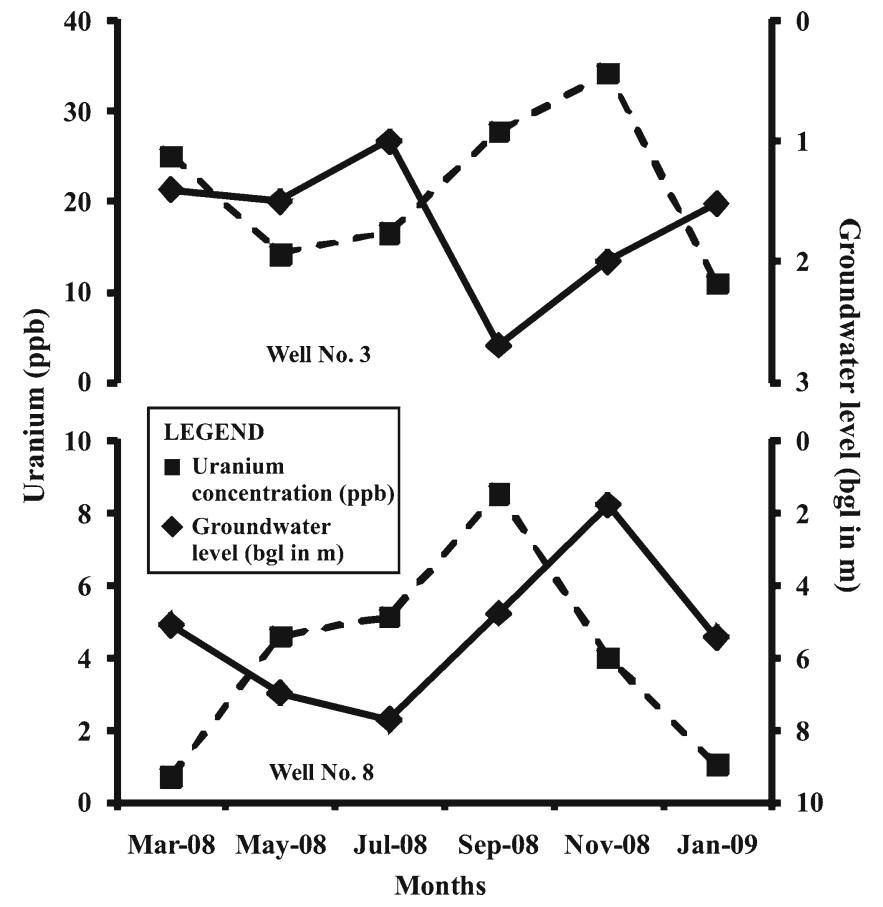

Figure 11. Temporal variation in groundwater level and uranium concentration.

Studying the spatial and temporal variation helps us to identify the contribution of various factors for the excess or low concentration of particular ions in groundwater. To understand the distribution of uranium in groundwater of the study area, iso concentration diagrams were prepared for all months.
Uranium concentration in groundwater of the study area varies spatially as well as temporally. Spatial variation in groundwater level and uranium concentration of the study area indicate that in general, the uranium concentration in groundwater increases along the flow direction (figure 10). The comparison between the uranium concentration and groundwater level in several wells indicate that the uranium concentration varies primarily due to recharge and discharge (figure 11). The rainfall recharge increases the groundwater level which in turn increases the uranium concentration in groundwater. The recharging water reacts with the weathered rocks in the unsaturated zone and the leached out uranium increases uranium concentration in groundwater. However, as the recharge continues concentration of uranium in groundwater begins to reduce due to dilution by comparatively fresh recharging water.

The granitic rocks which occur in most of the study area (figure 4) contain uranium in the range of 10.2-116 ppm (Shrivastava et al 1992). Interaction between these uranium rich weathered granitic rocks or top soil and groundwater has resulted in increase in uranium in this study area. The concentration of uranium is relatively high in three areas (figure 7). This is probably because of the presence of comparatively high uranium rich granitic rocks in these places.

In addition to the input derived from uranium rich rocks, use of phosphatic fertilisers for agricultural activity in this area may also add up to the uranium content in groundwater. Ioannides

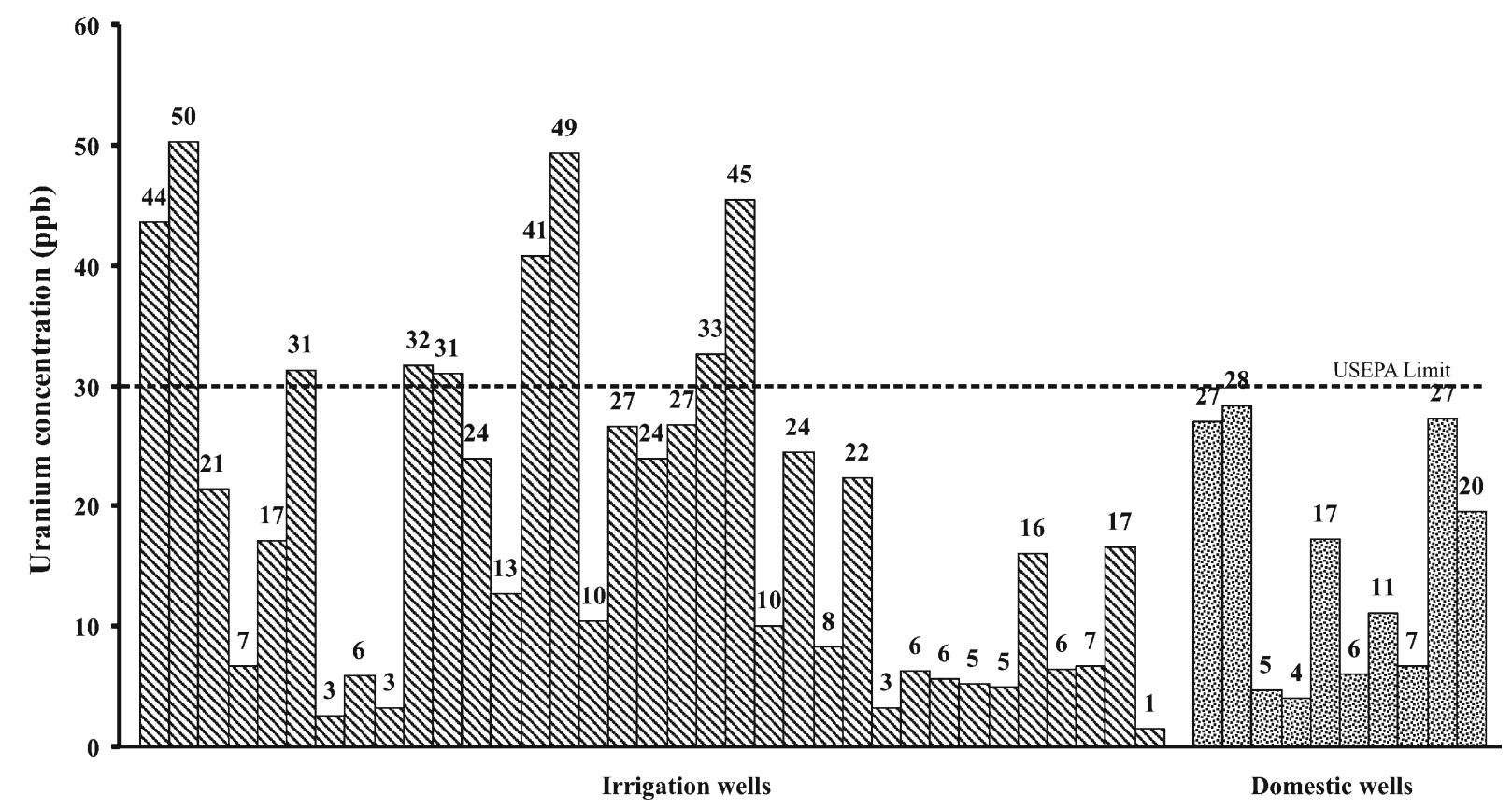

Figure 12. Average uranium concentration in groundwater (ppb) in irrigation and domestic wells. 
Table 2. Results of uranium concentration in fertilizers.

\begin{tabular}{lc}
\hline Fertiliser & $\begin{array}{c}\text { Uranium } \\
(\mu \mathrm{g} / \mathrm{g})\end{array}$ \\
\hline Zinc sulphate & 0.95 \\
Potash & 0.37 \\
Ammonium sulphate & 0.95 \\
Urea & 0.40 \\
NPK complex & 0.82 \\
\hline
\end{tabular}

et al (1997); Azouazi et al (2001); Papastefanou et al (2006); Roselli et al (2009) have reported the natural radioactivity in phosphatic fertilisers. The range of uranium content in the phosphate rock is about $0.005-0.02 \%$. These phosphate rocks serve as a source of phosphatic fertiliser to enhance the soil productivity in addition to other fertilisers. The total uranium resource in phosphate rock is estimated at $9 \times 10^{6}$ metric tonnes of uranium (Ragheb 2008). Hence, the phosphorous fertilisers manufactured form phosphate rocks may also contribute uranium to groundwater in the agricultural regions. Studies have shown that phosphate fertilisers possess uranium concentration ranging from $1 \mathrm{mg} / \mathrm{kg}$ to $68.5 \mathrm{mg} / \mathrm{kg}$ (Kawabata et al 2006). Concentration of fertilisers collected from this area varied from $0.37 \mathrm{ppb}$ to $0.95 \mu \mathrm{g} / \mathrm{g}$ (table 2 ). On an average, about $128 \mathrm{~kg} /$ hectare of fertiliser is being used in this area (Directorate of Economics and Statistics 2010). Considering an average uranium concentration of $0.7 \mu \mathrm{g} / \mathrm{g}$ of fertiliser will lead to an addition of about $89,600 \mu \mathrm{g}$ of uranium/year/hectare. Hence this also will add up to the uranium concentration in groundwater that resulted due to uranium rich rocks.

The average uranium concentration in groundwater of irrigation and domestic wells is given in figure 12. Although the uranium concentration in groundwater increases along the flow direction there is a difference between its concentration in domestic wells and irrigation wells. It is seen that more number of irrigation wells had uranium concentration above the permissible limit of $30 \mathrm{ppb}$. In case of domestic wells only one well had high uranium. Therefore the domestic wells have less concentration of uranium and thereby they can be considered to be safe for drinking purpose.

\section{Conclusion}

The uranium concentration in the groundwater of a part of Nalgonda district ranges from 0.2 to $68 \mathrm{ppb}$ with an average of $18.5 \mathrm{ppb}$. About $21.6 \%$ of the groundwater samples had uranium concentration above the limit (30 ppb) set by USEPA for drinking purpose. The uranium content in groundwater varies primarily due to recharge and discharge which would have dissolved or leached the uranium from the weathered soil to the groundwater zone. The groundwater uranium concentration varied similar to the variation in $\mathrm{pH}$. In general, the concentration of uranium in groundwater is high where the ORP is high. The uranium concentration was above $30 \mathrm{ppb}$ in three areas during the entire period of study. In order to decrease the uranium concentration in groundwater in this area, artificial groundwater recharge techniques such as rainwater harvesting can be adopted. It is important to continuously monitor the groundwater quality in this area to study the impact of uranium mineralisation.

\section{Acknowledgements}

The authors would like to thank the Board of Research in Nuclear Sciences, Department of Atomic Energy, Government of India for the financial support (Grant No. 2007/36/35). Assistance provided by Dr G K Shrivastava, Health Physics Unit, Nuclear Fuel Complex, Hyderabad, India for carrying out uranium analysis is acknowledged. Thanks are also due to Mr R Murugan and Mr R Rajesh, Research Fellows, Dept. of Geology, Anna University for their assistance during field visits. First two authors thank the Department of Science and Technology's Funds for Improvement in Science and Technology Scheme (Grant No. SR/FST/ESI-106/2010) and University Grants Commission's Special Assistance Programme (Grant No. UGC DRS II F.550/10/DRS/2007 SAP-1) for the financial support which helped in creating facilities to carry out part of this work.

\section{References}

Azouazi M, Ouahidi Y, Fakhi S, Andres Y, Ch Abbe J and Benmansour M 2001 Natural radioactivity in phosphates, phosphogypsum and natural waters in Morocco; J. Environ. Radioact. 54 231-242.

Babu M N S, Somashekar R K, Kumar A, Shivanna K, Krishnamurthy V and Eappen K P 2008 Concentration of uranium levels in groundwater; Int. J. Environ. Sci. Technol. 5(2) 263-266.

BIS 1993 Indian Standard Drinking Water-Specification (First Revision) IS 10500: 1991; pp. 1-8.

Brindha K, Rajesh R, Murugan R and Elango L 2011 Fluoride contamination in groundwater in parts of Nalgonda district Andhra Pradesh India; Environ. Monit. Assess. 172 481-492.

CGWB (Central Ground Water Board) 2007 Ground water information Nalgonda district, Andhra Pradesh; available from: http://cgwbgovin/District_Profile/AP/Nalgonda.pdf. 
Directorate of Economics and Statistics 2010 All-India Consumption of Department of Fertilisers in Terms of Nutrients $(\mathrm{N}, \mathrm{P}, \mathrm{K})$, Agriculture and Cooperation, Ministry of Agriculture, Government of India, available from: http://dacnet.nic.in/eands/latest_2006.htm.

Garshasbi H, Diba J K, Jahanbakhshian M H, Asghari S K and Heravi G H 2005 Measurements of natural uranium concentration in Caspian Sea and Persian Gulf water by laser flourimetric method; Iranian Journal of Radiation Research 3(3) 123-127.

GSI (Geological Survey of India) 1995 Geology and minerals map of Nalgonda district, Andhra Pradesh, India.

Ioannides K G, Mertzimekis T J, Parachristodoulou C A and Tzialla C E 1997 Measurements of natural radioactivity in phosphate fertilisers; The Science of the Total Environment 196 63-67.

Kawabata Y, Yamamoto M, Aparin V, Ko S, Shiraishi K, Nagai M and Katayama Y 2006 Uranium pollution of water in the western part of Uzbekistan; J. Radioanal. Nucl. Chem. 270(1) 137-141.

Kumar S A, Shenoy N S, Pandey S, Sounderajan S and Venkateswaran G 2008 Direct determination of uranium in seawater by laser fluorimetry; Talanta $7 \mathbf{7} 422-426$.

Papastefanou C, Stoulos S, Ioannidou A and Manolopoulo M 2006 The application of phosphogypsum in agriculture and the radiological impact; J. Environ. Radioact. 89 188-198.

Ragheb M 2008 Uranium resources in phosphate rocks, available from: https://netfilesuiucedu/mragheb/www/NPRE\% $20402 \% 20 \mathrm{ME} \% 20405 \% 20$ Nuclear\%20Power\%20Engineering/ Uranium\%20Resources\%20in\%20Phosphate\%20Rocks.pdf.

Ramola R C, Singh S and Virk H S 1988 Uranium and radon estimation in some water samples from Himalayas; Nuclear Tracks and Radiation Measurement 15(1-4) 791-793.

Rani A and Singh S 2006 Analysis of uranium in drinking water samples using laser induced fluorimetry; Health Physics 91(2) 101-107.

Reddy K V K, Reddy B S, Reddy M S, Reddy Ch G, Reddy P Y and Reddy K R 2003 Baseline studies of radon/thoron concentration levels in and around the Lambapur and Peddagattu areas in Nalgonda district, Andhra Pradesh, India; Radiat. Meas. 36 419-423.

Rengarajan R, Sarin M M and Krishnaswami S 2006 Dissolved uranium and ${ }^{234} \mathrm{U} /{ }^{238} \mathrm{U}$ in the Yamuna and the Chambal rivers, India; Aquatic Geochemistry 12 73-101.

Robbins J C 1978 Field technique for the measurement of uranium in natural waters; CIM Bulletin 71(793) 61-67.
Roselli C, Desideri D and Meli M A 2009 Radiological characterization of phosphate fertilisers: Comparison between alpha and gamma spectroscopy; Microchem. J. 91(2) 181-186.

Sarin M M, Krishnaswami S, Sharma K K and Trivedi J R 1992 Uranium isotopes and radium in the BhagirathiAlaknanda river system: Evidence for high uranium mobilization in the Himalaya; Curr. Sci. 62(12) 801-805.

Shawky S, Ibrahiem N, Farouk A and Ghods A 1994 Laser fluorimetric determination of uranium in environmental samples from Nile delta and adjacent region; Applied Radiation and Isotopes 45(11) 1079-1084.

Shrivastava V K, Parthasarathy $\mathrm{T}$ N and Sinha K K 1992 Geochemical study of uraniferous granites from Lambapur area, Nalgonda District, Andhra Pradesh, India; Exploration and Research for Atomic Minerals 5 $41-52$.

Singh B, Singh G, Sandhu A S and Singh S 1999 Uranium estimation in water samples collected from some areas of Himachal Pradesh, India; Radiat. Meas. 31 683-685.

Singh J, Singh L and Singh G 1995 High U-contents observed in some drinking waters of Punjab, India; J. Environ. Radioact. $26217-222$.

Singh J, Singh H, Singh S and Bajwa B S 2009 Estimation of uranium and radon concentration in some drinking water samples of Upper Siwaliks, India; Environ. Monit. Assess. 154 15-22.

Singh R V, Sinha R M, Bisht B S and Banerjee D C 2002 Hydrogeochemical exploration for unconformityrelated uranium mineralization: Example from Palnadu sub-basin Cuddapah Basin, Andhra Pradesh, India; J. Geochem. Explor. 76 71-92.

Singhal R K, Joshi S N and Hedge A G 2004 Association of uranium with colloidal and suspended particulate matter in Arabian Sea near the west coast of Maharashtra (India); J. Radioanal. Nucl. Chem. 2 263-267.

Sinha R M, Shrivastava V K, Sarma G V G and Parthasarathy T N 1995 Geological favourability for unconformity-related Uranium deposits in northern parts of the Cuddapah Basin: Evidences from Lambapur uranium occurrences, Andhra Pradesh, India; Exploration and Research for Atomic Minerals 8 111-126.

USEPA (United States Environmental Protection Agency) 2003 Current drinking water standards; Ground water and drinking water protection agency: Report prepared by Wade Miller Associates, pp. 1-12.

Zamora M L, Tracy B L, Zielinski J M, Meyerhof D P and Mossf M A 1998 Chronic ingestion of uranium in drinking water: A study of kidney bioeffects in humans; Toxicol. Sci. 43 68-77. 